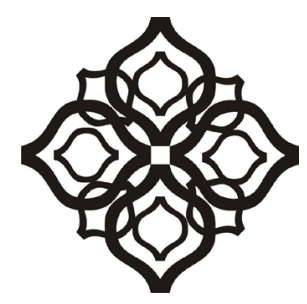

Shirkah

Journal of Economics and Business 


\section{Shirkah}

Journal of Economics and Business

Vol. 4, No. 1, January-April 2019

ISSN: 2503-4235 (p); 2503-4243 (e)

\section{Editor in Chief}

Fitri Wulandari

\section{Managing Editor}

Jasanta Peranginangin

\section{Editorial Boards}

Abdul Azim Islahi, Islamic Economics Institute, King Abdulaziz University, Saudi Arabia Abu Umar Faruq Ahmad, UBD School of Business and Economics Universiti, Brunei Darussalam Cedomir Nestorovic, ESSEC Business School Asia Pacific, Singapore

Fitri Wulandari, Faculty of Islamic Economics and Business, IAIN Surakarta, Indonesia Johan Fischer,

Department of Social Sciences and Business Roskilde Universitetscenter, Denmark Muhamed Zulkhibri, Islamic Research and Training Institute, Islamic Development Bank, Saudi Arabia M. Kabir Hassan,

Department of Economics and Finance, University of New Orleans, United States Musa Asy'arie,

Faculty of Islamic Economics and Business, IAIN Surakarta, Indonesia Nunung Nurul Hidayah, Aston Business School, Aston University, Birmingham, United Kingdom Saim Kayadibi,

Department of Economics, Kulliyyah of Economics and Management Science, International Islamic University Malaysia, Malaysia 
Shaikh M Ghazanfar,

Departement of Economics, University of Idaho, Russian Federation

Sigit S. Wibowo,

Department of Management, Faculty of Economics and Business, Universitas Indonesia, Indonesia

Vihang R. Errunza,

Desmarais Global Finance Research Centre, Desautels Faculty and Management, McGill University, Canada

\section{Assistant to Editor \\ M. Endy Saputro \\ M. Zainal Anwar}

Shirkah Journal of Economics and Business is a peer-reviewed journal published three times a year (January-April, May-August and September-December) by Faculty of Islamic Economics and Business, Institut Agama Islam Negeri (IAIN) Surakarta Central Java, Indonesia. The main objective of Shirkah is to offer an academic space of exchange ideas and initiate the increase number of qualified article produced by postgraduate students, practitioners and academicians.

\section{Editorial Office}

Ruang Jurnal Shirkah

Lantai Dasar, Sayap Barat, Fakultas Ekonomi dan Bisnis Islam, IAIN Surakarta

Jln. Pandawa No. 1, Kartasura, Sukoharjo, Jawa Tengah Kode Pos. 57168

Phone (+62271) 781516 Fax: (+62271)782336

E-mail: shirkahjournal@iainsurakarta.ac.id; shirkahiainsurakarta@gmail.com

Website: http://shirkah.or.id/ 


\section{Shirkah}

Journal of Economics and Business

Vol. 4, No. 1, January-April 2019

ISSN: 2503-4235 (p); 2503-4243 (e)

\section{Table of Contents}

\section{Articles}

Datien Eriska Utami

Identifying Financial and Non-Financial Factors as

the Determinant of Sukuk Rating in Indonesia

JM Muslimin

Halal Product Guarantee in

Indonesia Regulation and Social Inclusion

Isnan Indriati

Muh. Rudi Nugroho

Kuznet's Hypothesis and Ibn Khaldun's Socio-Economic Dimensions

Lucky Nugroho

Ahmad Badawi

Nurul Hidayah

Indonesia Islamic Bank Profitability 2010-2017

Aam Slamet Rusydiana

Lina Marlina

Lina Nugraha Rani

Malmquist Productivity Index on Islamic Economics and

Finance Research

Ahmad Farras Adibuddin

Doddy Setiawan

Bambang Sutopo

The Recent Development of Islamic Economic Studies in Indonesia 


\title{
Halal Product Guarantee in Indonesia Regulation and Social Inclusion
}

\author{
JM Muslimin \\ Graduate School, Universitas Islam Negeri (UIN) Syarif Hidayatullah Jakarta \\ jm.muslimin@uinjkt.ac.id
}

\begin{abstract}
Halal Product Guarantee Act exists to ensure the protection of halal products consumed by Muslim consumers. Since it contains rules that only lead to protecting certain segments of society (Muslim consumers), this rule has become controversial. It is alleged to be potentially discriminatory. An argumentative and critical study shows that this is not factual. Apart from being legally tested, the social facts show that the regulation can be a means for the process of social inclusion: a process where people can respect each other's communal rights, within the framework of authentic legal togetherness. The method employed is the analysis of legislation in a sociological perspective (sociological jurisprudence). The results of this study are through a series of juridical and sociological examinations, the Halal Product Guarantee Act can qualify as an integrative factor (social inclusion), in doing so it is expected to be an instrument of protecting people's rights (Muslim consumers' rights to get guaranteed halal products).
\end{abstract}

Keywords: social inclusion, regulation, halal product guarantee, consumer protection.

\section{Introduction}

In the international trade system, such matters relating to the guarantee of the halal status of a product are both a concern and a challenge, especially on consumer protection in international markets such as ASEAN-AFTA, NAFTA, the European Economic Community and the World Trade Organization (WTO). The international trade system has long known halal provisions in CODEX which are supported by influential international organizations including the World Health 
Organization (WHO), the Food Agricultural Organization (FAO) and the WTO. Furthermore, the halal life phenomenon is currently sweeping over parts of the world, including such global companies as Japan Airlines, Singapore Airlines, Qatar Airlines, American Airlines. Halal symptoms also penetrated the countries of Australia, Japan, China, India and Latin American countries.

In 2010 the World Halal Forum Europe was held in London. The forum presented many experts including legal experts. The theoretical and praxis developments were discussed. The main theme of the conversation was related to "Halal Products Halal Services-Going Mainstream". Six topics are the main issues: international halal accreditation and certification; European Union market issues and challenges; issues for guaranteeing food safety and quality for halal product business operators; the importance of halal sector growth in the current economic climate; growth of halal products in the retail markets of the European Union and the United Kingdom (UK); and influence of changes in the level of consumer preferences and concerns (Sholeh, 2015). The development of halal certification has also experienced rapid progress and positive acceptance from the community such as in India (Saeed \& Ondracek, 2004), Japan (MUI, 2015), and New Zealand (Wan Hassan \& Awang, 2009).

The high demand for halal products in Indonesia reflects an increasingly strong tendency towards lifestyle. Halal lifestyle has been implementing in the food sector, medicine, cosmetics and other consumer goods. Considering the large number of Muslim consumers in Indonesia which reached 204.8 million citizens, Indonesia has potentially been a large halal consumer market. The Indonesian government in fact has provided several regulations of halal products and production. In the initial stages, the response is still sectoral, not comprehensive and systemic, even seems 
to overlap. This is why there is no guarantee of legal certainty governing halal products, even though the need for halal product guarantees is a necessity and very urgent, especially in the protection of consumers and the global trade scene. It was issued later, Law No. 30 of 2014 concerning Halal Product Guarantee (UUJPH) which regulated the production chain from businesses to consumers (RFQ, 2014).

The enactment of UUJPH aims to ensure that consumers get legal certainty on food products and consumer goods, while for businesses as a guide to get halal certification. The purpose of UUJPH will have a positive impact on the business world considering that halal-certified products will be preferred and favored by consumers so as to increase the sale value of these products (Amin, 2010). It also means, from the aspect of legal theory and its relation to the social dimension, UUJPH bridges between various social components. Mainly, who care about halal issues. UUJPH provides a shared space so that all who have an interest in halal themes and issues can find common understanding as well as access to participation and constructive, sustainable and complementary roles (social inclusion) so that the audit process and halal certification can run in a participatory, transparent and accountable manner.

\section{A Legal Umbrella and Consumer Protection}

Law No. 8 of 1999 Concerning Consumer Protection (UUPK) is a legal umbrella for the implementation of consumer protection in Indonesia (Republic of Indonesia RI, 1999). Consumer Protection is any effort that guarantees legal certainty to provide protection to consumers (see Article 1 paragraph (1)) (Republic of Indonesia RI, 1999). Legal protection for consumers is basically a protection against the fulfillment of consumer rights that should be given to consumers (Sidabalok, 2006). The UUPK regulates consumer rights. One of the consumer's rights is regulated in 
article 4 letter a of the UUPK which determines that the consumer has the right to comfort, security and safety in consuming goods and/ or services. For Muslim consumers, one of the convenience of consumers in using products is a halal guarantee from businesses (Hasan, 2014).

The enactment of the Halal Product Guarantee Act (UUJPH) is a form of protection from the state for Muslim consumers in Indonesia. This is in accordance with article 29 paragraph (2) of the 1945 Constitution, which mandates that the state guarantees the independence of each resident to embrace their respective religions and to worship according to their religion and their beliefs, including providing protection and guarantees about the halal products consumed. Article 1 point 5 of the UUJPH states that the guarantee of halal products is legal certainty of the halal status of a product as evidenced by halal certification (see article 1 number 5) (Republic of Indonesia RI, 2014).

Under article 5 of the UUJPH, the implementation of halal product guarantees is the responsibility of the government (see article 5 paragraph 1, Republic of Indonesia RI, 2014). In this case implemented by the Ministry of Religion (see article 5 paragraph 2, Republic of Indonesia RI, 2014). For the implementation of halal product guarantees, the government established the Halal Product Guarantee Agency (BPJPH) which is under the Ministry of Religion. The authority of BPJPH is to issue and revoke halal certification on products that were previously carried out by the Indonesian Ulama Council for Food, Drug and Food Studies (LPPOM). With the enactment of UUJPH institutionally there will be a transfer of authority in issuing halal certification from LPPOM-MUI to BPJPH (Mertakusumo, 2006). 


\section{Between Practical and Effective Steps}

The idea of social inclusion promises practical and effective steps towards a more just society. Meanwhile, the idea of social exclusion has been realized by the existence of socially excluded groups and defined as those who are effectively prevented from participating in the benefits of citizenship or community membership due to various combinations of obstacles, mainly poverty and poor educational opportunities. In short, social inclusion offers protection of rights with substantive commitments to distribute justice or seek a more just society (Habermas, 1984, 2003; Matustík, 1993).

Social inclusion and egalitarian ideals share concerns about the results or patterns of access distribution within the community. Social inclusion does not seek the same or broadly equal results for all citizens. He focuses his attention not on the relative losses between groups, but rather on the absolute losses of certain groups in society. The goal, not to realize the idea of equality and comprehensive welfare, where all segments of society have their absolute space, but has focused on securing the level of welfare and freedom and minimum participation for every citizen. Utilizing this format, no segment has not left behind and discriminated against, but at the same time it has not been possible for all segments to get their absolute isolative space, giving rise to extreme social segregation (Habermas, 1984, 2003; Matustík, 1993).

The concept of social inclusion also always illustrates that citizens not only enjoy material welfare, but also must be able to achieve non-material comfort. This includes satisfactory levels of education, participation in politics, cultural activities, and employment. Individuals must be able to pursue their chosen goals in relation to these non-material goods to achieve a state of 'well-being'. Social inclusion is a theory of how society can be integrated and harmonious. In other words, the theory is that if everyone 
participates fully in society, they will not be alienated from the community and will adjust to social and legal rules. Social inclusion encourages social cohesion or, to use longer concepts, solidarity. Therefore, the results sought by social inclusion policies are not only justice for individuals, but also a stable social order. The importance of the relationship between social cohesion and social inclusion needs to be more emphasized (Habermas, 1984, 2003; Matustík, 1993).

The aim of social inclusion is to establish conditions and opportunities that encourage all citizens to participate in society and to respect the institution and its potential. Why is social inclusion interesting? Because it can provide answers to the question when the social system can be fair so that citizens can demand exactly the same treatment (absolute equality), and when it becomes fair even if the system deviates from that standard; take for an example, an anti-discrimination law that appears to be implicit in the purpose of social inclusion. It can be highlighted about four pillars: how social problems that must be addressed by antidiscrimination laws are contained in social inclusion policies; how social inclusion justifies deviations from the principle of equal treatment; is there a method of proving discrimination that is unlawful; and the extent to which the requirements for positive discrimination are in pursuit of social inclusion. This analysis allows to focus on identifying the extent to which justification of social inclusion can explain the purpose and content of the current law, although it also provides a critical perspective on possible deficiencies in the law. This concept and social landscape that the JPH Law will be explained and elaborated.

\section{Agency of The Legal Umbrella}

Law No. 30 of 2014 concerning Halal Product Guarantee serves as a legal umbrella to strengthen and regulate various halal regulations in 
various laws. It proposes to provide comfort, security, safety and certainty of the availability of halal products for the public in consuming and using products and to increase added value for businesses (see article 1 paragraph 1, Republic of Indonesia RI, 2014). In addition, this Law also continues to provide the role and function of each of the parties concerned in accordance with the stages of the procedure and their professional competence. Thus, this law can connect between institutions and establish a synchronous and coherent role participation (social inclusion), aiming to guarantee the existence of a trusted halal audit and certification process. Before the existence of this law, halal certification was voluntary; after the existence of UUJPH it became mandatory. Therefore, all products that enter, circulate and trade within the territory of Indonesia must be halal certified.

The institutional links and inclusive interconnections as described in the Law, can be described in the following. First, practices of organizing halal certification in Indonesia regarding Law number 33, 2014 on Halal Product Guarantee; the enactment brought fundamental changes related to the implementation of halal certification. Before the existence of this law, halal certification was carried out by LPPOM-MUI. After the existence of the law, it was carried out by BPJPH which is a body that will be formed by the government to organize halal product guarantees in Indonesia. Initially the establishment of the LPPOM-MUI was based on the government's mandate for the Indonesian Ulema Council (MUI) to play an active role in alleviating cases of pork fat in Indonesia in 1988. The LPPOM-MUI was established on January 6, 1989 to conduct halal examinations and certifications. To strengthen the position of LPPOM-MUI in carrying out the certification function, in 1996 a Memorandum of Understanding was signed between the Ministry of Religion, Ministry of Health and MUI with the issuance of the Minister of Religion Decree No. 518 of 2001 Guidelines and Procedures for Examination and Determination of Halal 
Food and Decree of the Minister of Religion No. 519 of 2001 concerning the Halal Food Examining Institution, which strengthens the position of LPPOM-MUI as a halal institution who establishes fatwas and issues halal certificates.

Halal certified by MUI which is addressed at food, health, cosmetics and other products provide certainty of halal status; it can be consumed in accordance with Islamic law. LPPOM-MUI in the process and implementation of halal certification cooperates with several ministries and institutions to accommodate the process of halal production so that it becomes feasible to be distributed. Regulations related to halal certification obligations are only voluntary (Hasan, 2014). This can be seen in the provisions of article 10 paragraph (1) government regulation no. 69 of 1999 concerning food labels and advertisements states that if the food is halal it must include information or be written "halal", furthermore article 11 paragraph (1) Government Regulation No. 69 of 1999 concerning food labels and advertisements determines that in order to support the truth of the halal statement, it must be examined by an accredited inspection body. Based on this rule, it can be concluded that halal certification is only required if the business actor includes a halal label on the product packaging.

The halal certification process carried out at MUI is basically carried out by LPPOM-MUI. Starting from the registration, inspection and product testing to the issuance of halal certificates. In general, halal certification procedures are as follows (During LPPOM-MUI's handling) (Hasan, 2014):

a. Companies that apply for certification, whether new registration, development (products/ facilities) and renewals, can register online through the LLPOM-MUI website. 
b. Fill in the registration data: certification status (new/ development/ renewal), halal certificate data, Halal Assurance System status (if any) and product groups.

c. Pay the registration fee and halal certification contract fee.

d. Fill in the documents required in the registration process in accordance with the status of the registrant (new/ development/ renew) and business processes (processing industry, abattoir, restaurant and service industry).

e. After completing the required documents, the next step is in accordance with the halal certification process flowchart, as above, namely the examination of the adequacy of the document.

The halal certificates obtained from LPPOM-MUI is valid for 2 years (MUI, 2014). In contrast to the provisions of article 42 paragraph (1) of the UUPJH, it is determined that the halal certificate issued by BPJPH is valid for 4 years. The halal certificate must be extended by business actors by submitting a halal certificate renewal no later than three months before the validity of the halal certificate expires. The practice of implementing halal certificates in Indonesia based on the UUPJH determines that as long as BPJPH has not been formed, halal certificates will still be implemented by LPPOM-MUI. The implementation of halal certificates carried out by LPPO-MUI is not mandatory. The object of halal certificate does not cover all goods and services, but only applies to goods. Such conditions certainly cannot provide legal certainty for the guarantee of halal products for Muslim consumers in Indonesia.

Second, the concept of the agency for providing Halal Product Assurance (BPJPH) in organizing Halal certification in Indonesia; $\mathrm{BPJPH}$ is an institution formed with the authority to hold halal product guarantees in Indonesia. The aim is to provide comfort, security, safety and certainty of the availability of halal products for the community. Among BPJPH's 
authorities are formulating and establishing halal product guarantees, establishing norms, standards, procedures and criteria for halal product guarantees and issuing and revoking halal certificates and halal labels (see article 6, Republic of Indonesia RI, 2014). BPJPH in exercising that authority collaborates with related institutions.

As already explained, that halal guarantee regulations are not intended to monopolize all procedures, checks and testing in the context of labeling/ certification in the hands of only one institution. However, inclusively encouraging coordination and synchronization of the task chain between institutions. The institutional and administrative social inclusion is: that the interconnection and integration of the coordination relationship between the BPJPH under the Ministry of Religion and related ministries and institutions is illustrated as follows:

a. BPJPH with the Ministry of Trade:

Implementation in collaboration with the Ministry of Trade in this case is the Directorate of Standardization and Consumer Protection (Directorate of Decree). The form of coordination and cooperation between BPJPH and the Ministry of Trade is in terms of determining obligations for business operators in Indonesia and from abroad who will enter Indonesia to certify and label product related to the halal status of a product.

b. BPJPH with the Ministry of Health:

BPJPH collaboration with the Ministry of Health is related to the supervision of medicines and medical devices.

c. BPJPH with the Food and Drug Monitoring Agency (BPOM):

Collaboration that can be carried out with the authority of BPOM in supervising products that are circulating in the community. BPOM can carry out inspection and testing of goods products that have been circulating in the community, both those that have been halal certified 
or not. Examination and testing is related to the ingredients contained in the product.

d. BPJPH with the Ministry of Industry

To provide guidance to business actors related to the procurement of raw materials. The production process must also meet the halal standards and conditions of a product.

e. BPJPH with the Ministry of Finance:

Related to determining tariffs and financial management of BPJPH as a Public Service Agency (BLU) which will provide guidance, assistance, and consultation in the preparation of tariffs and submit recommendations to the Minister of Finance regarding the determination of tariff proposals.

f. BPJPH with the Ministry of Agriculture:

Related to food and animal control. The purpose of food control is related to the use of chemical substances in food products that contain non-halal elements. As for animal control that is carried out by raising animals using substances or vaccines that are not necessarily clear of their halal status.

g. BPJPH with the National Accreditation Committee (KAN) and the National Standardization Agency (BSN):

Namely related to accreditation and certification standards. Coordination related to the halal standardization of a product is carried out in the framework of compiling accreditation standards for BPJPH and accreditation of LPH to meet the standards set by BSN.

h. BPJPH with the Ministry of Cooperatives and SMEs:

That is related to this coaching and development is to provide awareness to businesses about the importance of halal certification of a product. Coordination is also related to facilitation to cooperatives and SMEs related to financing halal certification. 
Equally important to be elaborated is the form of cooperation between BPJPH and the Indonesian Ulama Council (MUI) in providing halal product guarantees. This was carried out in the context of halal auditor certification, halal fatwa stipulation, and accreditation of the Halal Examining Institution (LPH). MUI continues to play a role as an authority and provider of religious legitimacy in establishing halal fatwas for products that are requested for halal certification from BPJPH (Republic of Indonesia RI, 2014). Meanwhile, the form of cooperation between BPJPH and Halal Examination Institution (LPH) is carried out by product testing and checking. Before LPH is given the authority to carry out product inspection, accreditation must first be carried out by $\mathrm{BPJPH}$. In the testing and inspection of products by $\mathrm{LPH}$, the inspection and testing are carried out by the LPH halal audit.

The issue of Muslim consumer protection related to halal certification is not only seen from the BPJPH context. However, in the context of the implementation of halal certificates, it must also be seen from the relevant ministries and institutions. The issue of organizing halal product guarantees does not merely address issues concerning halal certification, but also matters relating to the implementation of halal product guarantees. In summary, it can be concluded that BPJPH, as an institution, has the following authority (see article 6, Republic of Indonesia RI, 2014): formulating and establishing a halal product guarantee policy; establishing norms, standards, procedures and criteria for halal product guarantee; issuing and revoking Halal Certification on products; registering Halal certification on imported products; accrediting the Halal Inspectorate Institution (LPH); registering Halal Auditors; supervising halal product guarantees; coaching halal auditors; cooperating with domestic and foreign institutions in the field of halal product guarantee. 
To assist BPJPH in carrying out inspection and/ or testing of halal products, the government and the community can establish a Halal Examination Institution (LPH) with the following conditions (see article 10, Republic of Indonesia RI, 2014): have your own office and equipment; has accreditation from BPJPH; have at least 3 Halal Auditors; and having a laboratory or cooperation agreement with another institution that has a laboratory. UUBPJPH also opens opportunities for other institutions besides LPPOM-MUI to establish LPH. Islamic mass organizations at the central as well as regional levels, such as Muhammadiyah and Nahdatul Ulama (NU) as well as regional campuses that have the ability to handle halal products in the fields of food, health and cosmetics can be included in the context of the implementation of halal products for consumers.

\section{Social Inclusion versus Discrimination}

Public and parliamentary debates towards the ratification of the JPH Law have intensively continued more than eight years. Several debatable problems are Halal labeling between voluntary or mandatory, Status of the Halal Insurance Agency (LPH) and Government Authority or the Indonesian Ulama Council (MUI) for the certification and labeling. The dynamics of the ongoing debate about the three themes above shows the participation of the public and all components of civil society. The following is a summary of the anatomy of the debate that took place in parliament ahead of the drafting of the Act. Involved were Prosperous Justice Party (FKS) Faction, Indonesian Democratic Party of Struggle (PDI-P), Golongan Karya (Golkar), National Mandate Party (PAN), United Development Party (PPP), National Awakening Party (PKB), Democratic Party, Great Indonesia Movement Party (Gerindra), and People's Conscience Party (Hanura) (Jahar \& Thalhah, 2018). 
Table 1. Certification and Halal Labeling Between Mandatory and Voluntary

\begin{tabular}{ll}
\hline \multicolumn{1}{c}{ Fraction $(\mathrm{F})$} & \multicolumn{1}{c}{ Political Attitude } \\
\hline F.PKS & $\begin{array}{l}\text { Halal certification and labeling are mandatory or } \\
\text { mandatory with a transition period of 5 years }\end{array}$ \\
\hline $\begin{array}{l}\text { F.PDI P, F.Golkar } \\
\text { (F.PAN, F.PPP, F.PKB, },\end{array}$ & $\begin{array}{l}\text { Prefer voluntary or voluntary, judging by business } \\
\text { actors and the products produced, not all } \\
\text { F.Demokrat, F.Gerindra and } \\
\text { F.Hanura) }\end{array}$ \\
& $\begin{array}{l}\text { especially for non-Muslims. The economic aspects } \\
\text { promoted by golkar in choosing voluntary traits. }\end{array}$ \\
\hline
\end{tabular}

Table 2. Status of the Halal Product Guarantee Agency under Government

\begin{tabular}{ll}
\hline \multicolumn{1}{c}{ Fraksi (F) } & \multicolumn{1}{c}{ Political Attitude } \\
\hline F.PKS & $\begin{array}{l}\text { The Halal Product Guarantee Agency is under the } \\
\text { President. }\end{array}$ \\
\hline $\begin{array}{l}\text { F.PDI P (F.Golkar F.PAN, } \\
\text { F.PPP, F.PKB, F.Demokrat, }\end{array}$ & $\begin{array}{l}\text { Not specifically commenting on the halal product } \\
\text { guarantee agency whether under the president or } \\
\text { the Ministry of Religion (government). It seems to } \\
\text { approve as stated in the RUU JPH. }\end{array}$ \\
\hline
\end{tabular}

Table 3. The Faction that Supports the MUI or the New Institution

\begin{tabular}{ll}
\hline \multicolumn{1}{c}{ Fraksi (F) } & \multicolumn{1}{c}{ Political Attitude } \\
\hline F.PKS & Supports MUI \\
\hline F.PAN & $\begin{array}{l}\text { Initially supported the MUI as part of the National } \\
\text { Agency for Guarantor for Halal Products, but later } \\
\text { fully supported the MUI for economic reasons. } \\
\text { Establishment of new institutions hiqh cost }\end{array}$ \\
\hline F.PDI P & F.PKB, \\
\hline $\begin{array}{l}\text { F.Golkar, } \\
\text { F.Demokrat, } \\
\text { F.Hanura) }\end{array}$ & F.Gerindra case it supports MUI more \\
& $\begin{array}{l}\text { Do not give comments publicly about their support } \\
\text { to the MUI as the guarantor institution for halal } \\
\text { products, so their views are assumed to be the same } \\
\text { as stated in the RUU JPH. }\end{array}$ \\
\hline
\end{tabular}




\section{External Inclusion: Test of Constitutionality}

The Halal Product Guarantee Act (JPH Law) is not necessarily acceptable to all groups. He must pass his constitutionality test in the Unitary State of the Republic of Indonesia based on Pancasila. In this country all residents and citizens of whatever religion they come from, their rights are guaranteed the same by law. If there is a right that will be threatened because the product of a regulation, the constitutionality test facility is available through the Constitutional Court (MK). In the context of the JPH Law, Paustinus Siburian acts as the applicant for judicial review to the Constitutional Court. The Petitioner considered the JPH Law to generalize all religions as those who knew the concept of haram (or halal). And everyone needs halal guarantees, as stated in the objectives of the JPH Law which are actually contrary to Article 29 paragraph (1) of the 1945 Constitution. Entry, circulation and trade in the territory of Indonesia must be halal-certified.

According to the Petitioner, the obligation to include non-halal information on the product packaging or on the product itself is very detrimental to the Applicant. For whom should there be any unlawful assertion? Because, not halal according to Islamic law does not mean unlawful according to other religions / groups. If in the packaging or parts of the product it only says "not halal". For this reason, the Petitioner asked the Constitutional Court to state that the article being tested had no binding legal force and was contrary to the 1945 Constitution. The Constitutional Court (MK) rejects the applicant's judicial review for the weighing section in letter $b$ and for a number of articles Article 1 number 1; Article 3 letter a; Article 4; Article 26 paragraph (2); Article 65; and Article 67 of the JPH Law. Regarding the halal certification process and the definition of halal products in Law Number 33 of 2014 concerning Halal Product Guarantee (JPH Law). 
The articles basically regulate the obligation of halal certification which has been decided by the Constitutional Court which is also questioned by Paustinus Siburian. In the decision numbered 5 / PUU-XVI / 2017, the Court stated that it did not accept it because it considered its application to be vague or unclear. The Court did not understand what the Petitioners really wanted. Quoting this petition, the considering section b between the words "religion" and "for" should have the word "Islam" inserted. Likewise, the word "community" should be "Muslim". The Petitioner reasoned that the objective of the JPH Law is to guarantee that all adherents of "Islam" religion to worship and carry out their religious teachings, the state is obliged to provide protection and guarantees about the halal products consumed and used by "Muslims".

Considering the letter $\mathrm{b}$ is "that to guarantee every religious adherent to worship and carry out his religious teachings, the state is obliged to provide protection and guarantee about the halal products consumed and used by the public." In fact, in Article 1 number 2 of the JPH Law it is stated, "Halal Products are Products that have been declared halal in accordance with Islamic law." In its consideration, the Court considered that the provision of halal product guarantees was not an effort to apply Islamic law to all people, including non-Muslim communities. Sociologically, the JPH Law aims to provide legal protection in the form of guaranteed halal products that are consumed or used by Muslims in accordance with the teachings of their religion.

"However, it does not mean that a halal product is guaranteed to obstruct the people who want to consume non-halal products," said on the decision number 8 /PUU-XVII/ 2019. Constitutionally, the entry into force of the JPH Law is a manifestation of the responsibility of the state to protect the rights of the community to guarantee a healthy and protected life in worship according to the teachings of their religion guaranteed by 
the 1945 Constitution. A Muslim must fulfil the demands of the Islamic Sharia which forbid certain products to be consumed. Therefore, without a law that regulates the demands of these needs will cause difficulties for Muslim communities to meet the guidelines of Islamic law. There is no relation at all of the enactment of Law 33/2014 with efforts to implement Islamic law to all people, including non-Muslim communities, as the Petitioners are concerned. "Based on the entire description of the legal considerations, all petitioners' petition with regard to the constitutionality of norms of Law 33/2014 submitted for testing is groundless according to law."

\section{Participation and Empowerment}

A law is said to be prepared with the principle of inclusive and participatory, if the drafting process involves all components of society and proceeds with a systematic and gradual process. UUJPH has gone through these stages and processes. The law was discussed and discussed through various stages in the flow of the National Legislation Program (Prolegnas). In the final stages before it was ratified, various kinds of debates also appeared in parliament. Including from non-Muslims. The debate from the beginning also emphasized that in the future implementation of this law, it would not kill the potential and the elements of community power. Especially those who have been gathered in the Community Organization. The emergence of this Act is also expected not to plunge the Unitary Republic of Indonesia (NKRI) into a religious state or a state that only prioritizes services to one particular religious group (Islam) (Jahar \& Thalhah, 2018).

Because through a series of open debates above, from sociological perspective it can be representative of internal social inclusion and external social inclusion. What is meant by internal social inclusion is that the JPH 
Law does not kill the role of the Religious Social Organization (Islam). These organizations can continue to play a role in creating and establishing Halal Examination Institutions ( $\mathrm{LPH})$, the process of making fatwas, as well as halal auditor certification and LPH accreditation(see article 10, Republic of Indonesia RI, 2014). Meanwhile, regarding external inclusion, the existence of this Law would not actually have discrimination for nonMuslims. Therefore, producers who will get halal certificates are not only Muslim producers.

As long as the halal terms and conditions of a product are obeyed, the certificate can be owned by anyone; do not look at the setting of confessional (religion). This law is also not intended to eliminate and prohibit non-halal products in circulation. The law only intends to protect Muslim consumers who pay attention to the halal standardization of products consumed. This is in line with the constitution (article 29) and in line with the Law on Consumer protection. Because of this inclusive regulatory style, its presence is very much expected. Even though there has been an attempt to do a judicial review of this law, it has survived and was not canceled by the Constitutional Court (MK) (Sahbani, 2019).

\section{Conclusion}

Law Number 30 of 2014 concerning Halal product guarantees reinforces the issue of halal-haram in the production chain from businesses to consumers. Before the formation of Law Number 30 of 2014 concerning Halal product guarantees, there was Law Number 18 of 2012 concerning food; Law No. 36/2009 concerning health, Law No. 8/1999 concerning consumer protection, Government regulation No. 69/1999 concerning food labeling and advertising, Presidential Instruction (Inpres) 1991 concerning enhancement of guidance and supervision of the production and distribution of processed foods, Joint Ministerial Decree. 
Aside from law aimed at guaranteeing halal product guarantees in addition to providing protection and guarantees to consumers, it is also beneficial for producers to provide guidance on how to process, produce, and distribute products to the public. Considering that the issue of regulating halal products has long been necessary both in the context of the circulation of prohibitions on a domestic scale and the circulation of global goods, the drafting of implementing regulations from UUJPH and the establishment of BPJPH as the guardian of halal products in Indonesia needs to be speeded up in the process so that UUJPH can effectively protect Indonesian consumers.

There is an affirmation of the role of each institution related to the halal certification and labeling process; in turn UUJPH is inclusive. It is not intended to turn off social-community institutions, for example Nahdhatul Ulama, Muhammadiyah, and Indonesian Ulama Council; yet it provides opportunities to become halal assessors for individuals or form Halal Assurance Institutions (LPH). Furthermore, they can actively participate in the process of establishing halal certification (fatwa). However, this does not mean that in the future the halal certification and labeling process will not be issued easily. The technical rules as a translation of UUJPH have not yet been published. In addition, an inclusive certification process and based on community participation also has the potential to produce varied legal opinions. In the near future, it is also possible, with the existence of several LPHs standing, then the normative criteria for the halal of a product will potentially vary according to the orientation of the thought of the respective LPHs. 


\section{References}

Amin, M. (2010). Fatwa Produk Halal: Melindungi dan Menentramkan. Jakarta: Pustaka Jurnal Halal.

Charity, May Lim. (2017). Jaminan Produk Halal di Indonesia. Jurnal Legislasi Indonesia, 14 (01), 99-108

Habermas, J. (1984). The Theory of Communicative Actiont: Reason and the Rationalization of Society (T. McCarthy, Trans. Vol. 1). Boston: Beacon Press.

Habermas, J. (2003). Truth and Justification (B. Fultner, Trans.). Cambridge: Polity Press.

Hasan, Sofyan. (2011). Sertifikasi Halal dalam Hukum Positif, Regulasi dan Implementasinya di Indonesia. Jakarta: Kementerian hukum dan Hak Asasi Manusia Badan Pembinaan Hukum Nasional.

Hasan, K. S. (2014). Kepastian Hukum Sertifikasi dan Labelisasi Halal Produk Pangan. Jurnal Dinamika Hukum, 14(2), 227-238.

Jahar, A. S., \& Thalhah. (2018). Dinamika Sosial Politik Pembentukan Undang-Undang Jaminan Produk Halal. AL-IHKAM: Jurnal Hukum \& Pranata Sosial, 12(2), 385-404.

Janzuni. (2005). Legislasi Hukum Islam Di Indonesia. Bandung: Citra Aditya Bhakti.

Matustík, M. J. (1993). Postnational Identity: Critical Theory and Existential Philosophy in Habermas, Kierkegaard, and Havel. New York: Guilford Press.

Masudi, Masdar Farid. 2014. Syarah Konstitusi UUD 1945 dalam Perspektif Islam. Jakarta: Pustaka Alvabet.

Mertakusumo, S. (2006). Penemuan Hukum: Sebuah Pengantar. Yogyakarta: Liberty.

MUI. (2014). Prosedur Sertifikasi Halal MUI. Retrieved 20 August, 2019, from http://www.halalmui.org/muil4/index.php/main/go_ 
to_section/56/1362/page/1

MUI. (2015). Japan Halal Expo 2015. Jurnal Halal, XVIII(113).

RFQ. (2014). UU Jaminan Produk Halal Berikan Kepastian Hukum Bagi Konsumen. Retrieved 19 August, 2019, from https:/www. hukumonline.com/berita/baca/lt54241d9c5a5ed/uu-jaminanproduk-halal-berikan-kepastian-hukumbagi-konsumen.

Law of The Republik Indonesia Number. 8 year 1999 Concerning Consumer Protection (1999).

Law of The Republic Indonesia Number 33 year 2014 Concerning Guaranteed Halal Products About Consumer Protection (2014).

The Premier Global Halal Industry Event: World Halal Forum Europe (The Executive Review), London, UK, 10-11 November 2010 di London.

Saeed, Y., \& Ondracek, J. (2004). Dakota Halal Processing: A Case Study and Halal Food Management Framework. Delhi Business Review, 5(2), 33-45.

Sahbani, A. (2019). Alasan MK Tolak Uji UU Jaminan Produk Halal. Retrieved 27 Augus, 2019, from https://www.hukumonline.com/ berita/baca/lt5c9baa64ef2bf/alasan-mk-tolak-uji-uu-jaminanproduk-halal/

Shidarta. (2004). Hukum Perlindungan Konsumen. Jakarta: Gramedia.

Sholeh, A. N. a. (2015, 22 July 2015). Halal Jadi Tren Global. Gatra.

Sidabalok, J. (2006). Hukum perlindungan Konsumen di Indonesia. Jakarta: Gramedia.

Suntana, Ija. 2014. Politik Hukum Islam. Bandung: CV Pustaka Setia.

Suparto, Susilawati, et.al. (2016). "Harmonisasi dan Sinkronisasi Pengaturan Kelembagaan Sertifikasi Halal Terkait Perlindungan Muslim Indonesia”. Mimbar Hukum, 28 (3), 427-438

Wan Hassan, W. M., \& Awang, K. W. (2009). Halal food in New Zealand restaurants: an exploratory study. International Journal of Economics and Management, 3(2), 385-402. 
Vol. 4 No. 1, January - April 2019 


\section{Shirkah Author Guidelines}

Shirkab currently offers two routes to submit manuscripts. We highly recommend to submit the articles which are made using OJS (Open Journal System). Feel free register as author soon through visiting http://shirkah. or.id/index.php/home/user/register. The authors may directly send their manuscripts, along with their resume, to shirkahiainsurakarta@gmail. com. Please prepare your manuscripts, using following guidelines:

1. Manuscript must be written in English. Submitted articles should not have been published or be under review for publication with another journal.

2. Manuscript's length is about $15-20$ pages, typed in one-half spaced on A4-paper size.

3. Manuscript must include an $150-200$ word abstract and keywords.

4. Manuscript must be arranged as follows: Title, Name of Author, E-mail address, Abstract, Keywords, Introduction (including method if any), Discussion, Conclusion, References.

5. Manuscript's titles not more than ten words.

6. Manuscript must be submitted in Microsoft Word or RTF.

7. Arabic words should be transliterated according to the style of International Journal of Middle Eastern Studies.

8. Manuscript references are preferably derived from the up-to-date references.

9. The author's resume should be submitted separately, consisting of at least full name, institutional address, phone number, areas of studies, and recent publications (if any).

10. Shirkab use APA Style 6th edition (2010) as reference format writing. We suggest the use of a reference manager software such as Mendeley, Zotero, and Endnote at templating the citation style. APA Style to be used is as follows: 


\section{Book with single author}

Swann, G. M. Peter. (2014). The Economics of Innovation an Introduction. Cheltenhum \& Northampton: Edward Elgar.

in-text citation: (Swann, 2014)

\section{Articles in reference books}

Alatas, S. F. (2006). Islam and the Science of Economics in Abu Rabi', I.M. The Blackwell Companion to Contemporary Islamic Thought. USA: Willey-Blackwell (pp. 587-606).

in text citation: (Alatas, 2006)

\section{E-Book}

Hackett, Rosalind (2007). "Religous Dimentions of War and Peace: Introduction." Dalam Gerrie ter Haar dan Yoshio Tsuruoka (Ed.), Religion and Society: An Agenda for the 21st Century (h. 3-6). Retrieved from http:// brill.nl.

in text citation: (Hackett, 2006)

\section{Master's thesis, from a commercial database}

McNieI, D. S. (2006). Meaning through narrative: A personal narrative discussing growing up with an alcoholic mother (Master's thesis). Available from ProQuest Dissertations and Theses database. (UMI No. 1434728)

in text citation: (Mc Niel, 2006)

\section{Doctoral dissertation, from an institutional database}

Adams, R. J. (1973). Building a foundation for evaluation of instruction in higher education and continuing education (Doctoral dissertation). Retrieved from http://www.ohiolink.edu/etd/

in text citation: (Adams, 1973) 


\section{Doctoral dissertation, from the web}

Bruckman, A. (1997). MOOSE Crossing: Construction, community, and learning in a networked virtual world for kids (Doctoral dissertation, Massachusetts Institute of Technology). Retrieved from http:/www-static. cc.gatech.edu/--asb/thesis/

in text citation: (Bruckman, 1997)

\section{Journal article with No DOI}

Bourkhis, K., and Nabi, M. S. (2013). Islamic and conventional banks' soundness during the 2007-2008 financial crisis. Journal Metrics, 22(2), 68-77.

in-text citation: (Bourkhis \& Nabi, 2013).

\section{Journal article with DOI}

Ichwan, M. (2012). The Local Politics Of Orthodoxy: The Majelis Ulama Indonesia in the Post-New Order Banten. Journal Of Indonesian Islam, 6(1), 166-194. doi:http://dx.doi.org/10.15642/JIIS.2012.6.1.166-194

In text citation : (Ichwan, 2012)

\section{Abstract as citation}

Hasan, N. (2012). Islamist Party, Electoral Politics And Da'wah Mobilization Among Youth : The Prosperous Justice Party (PKS) in Indonesia. Journal of Indonesian Islam, 6(1), 17-47. Abstract from http://jiis.uinsby. ac.id/index.php/jiis/article/view/97

in text citation : (Hasan, 2012)

\section{Mass media article}

Sahal, Akhmad (2014, March 2). Kiai Sahal dan Realisme Fikih.Tempo Magazine, p. 120.

in text citation : (Sahal, 2014) 


\section{Research report}

Fisher, B. S., Cullen, F. T., \& Turner, M. G. (2000). The Sexual Victimization of College Women. Research Report.

in text citation : (Fisher, Cullen, Turner, 2000)

\section{Monograph}

Routray, Bibhu Prasad (2013), National Security Decision-Making in India (RSIS Monograph No. 27). Singapura: Rajaratnam School of International Studies.

in text citation : (Routray, 2013)

\section{Proceeding article}

Sudibyakto, Hizbaron, D.R., \& Jati, R (Ed.) (2009), Proceeding International Seminar Disaster Theory, Research and Policy. International seminar held by Sekolah Pascasarjana, Universitas Gajahmada, Yogyakarta, 8-9 Desember 2009.

in text citation : (sudibyakto and Jati, 2009)

\section{Paper conference/seminar/symposium}

Janutama, Herman Sinung (2011). "Kraton dan Hubungan Antar Agama." Paper presented in Seminar Kraton dan Panatagama held by Center for the Study of Islam and Social Transformation (CISForm), Yogyakarta, 17 November.

in text citation :(Janutama, 2011)

\section{Online article in web}

Shiva, (2006, February). Bioethics: A Third World Issue. Native-web. Diperoleh dari http://www.nativeweb.org/ pages/legal/shiva.html

in text citation : (Shiva, 2006) 


\section{Online research report}

Kessy, S. S. A., \& Urio, F M. (2006). The contribution of microfinance institutions to poverty reduction in Tanzania (Research Report No. 06.3). Retrieved from Research on Poverty Alleviation website: http://www.repoa.or.tz/documents_storage/Publications/Reports/06.3_Kessy_and_ Urio.pcif

in text citation : (kessy and urion, 2006)

\section{Holy book}

Qur an, $2(25)$

In text citation : (Q. al-Baqarah 2:25).

\section{Encyclopaedia}

Graycar, Adam (1992). Social Welfare Policy. Dalam Mary Hawkesworth dan Maurice Kogan (Ed.), Encyclopedia of Government and Politics (Vol. 1). London: Routledge.

in text citation : (Graycar, 1992)

\section{Interview}

Sultan Hamengkubuwono X (interview, 2011, April 19)

in text citation: (Hamengkubuwono, 2011)

\section{Documentary film}

Steijlen, Fridus (2008). A Day in the Life of Indonesia [documentary film, 58 minutes]. Leiden: KITLV Press.

in text citation : (Steijlen, 2008) 
Vol. 4 No. 1, January - April 2019 